\section{Effect of Length of Exposure to Cell-free Medium from Mixed Leucocyte Cultures on Blastogenesis in Leucocyte Cultures from Single Subjects}

MAterial which stimulates blastogenesis of allogeneic leucocytes is released into the surrounding medium when human leucocytes are cultured in vitro ${ }^{1-3}$. Wo havo investigated the effect of length of exposure to cell-free medium from mixed leucocyte cultures on blastogenesis in leucocyte cultures from single donors. We also found the minimum volume of cell-free culture medium which stimulates DNA synthesis in cultures of leucocytes from single donors.

The subjects were healthy volunteers; the culture technique has already been described ${ }^{4}$. The leucocytes were washed once with medium 199 and were resuspended in fresh plasma from several donors. The cell suspensions were diluted with medium 199 so that the final plasma concentration was 20 per cent and the leucocyte count was $1,500 / \mathrm{mm}^{3}$. The cell suspensions were incubated in $17 \times 100 \mathrm{~mm}$ disposable plastic culture tubes. Cell-free culture medium was prepared from 5-day mixed leucocyte cultures as described previously ${ }^{1}$. In experiments investigating the relation of volume of cell-free culture medium to stimulatory activity, various volumes of the medium were added to freshly prepared leucocyte cultures from single donors. The total volume in each culture tube was $4 \mathrm{ml}$. In experiments to determine the effect of length of exposure to cell-free medium on blastogenesis saline, and then twice in 5 per cent trichloroacetic acid. DNA was extracted by the Schmidt-Tannhauser technique $^{5}$, except that the concentration of potassium hydroxide was decreased to $0.5 \mathrm{~N}$. The radioactive content of the DNA fraction was counted in a liquid scintillation counter. Quenching was measured by an internal standardization method ${ }^{6}$ using ${ }^{3} \mathrm{H}$-toluene as the internal standard. Quenching was similar for the samples tested. The concentration of DNA present in each preparation was determined by measuring the optical density at $260 \mathrm{m \mu}$ in a spectrophotometer with a hydrogen lamp. The results were expressed as c.p.m. per $10 \mu \mathrm{g}$ of DNA.

Table 1 shows that the stimulatory activity of cell-free culture medium was increased by increasing the volume of the medium added. Stimulation induced by $4 \mathrm{ml}$. of cell-free medium was greater than that by $2 \mathrm{ml}$. (ref. 1). There was no stimulatory activity with $0.25 \mathrm{ml}$. of cellfree culture medium. When $0.5 \mathrm{ml}$. of cell-free medium was added, DNA synthesis was slightly but consistently higher than in control cultures of unmixed leucocytes.

Table 2 shows the effect of length of exposure to cellfree culture medium on blastogenesis in cultures of leucocytes from single donors. When the stimulatory medium was removed after the first $60 \mathrm{~min}$ incubation, DNA synthesis was consistently higher than in unstimulated control cultures. In some cases (experiments 1 and 2 in Table 2) DNA synthesis was significantly increased with exposure for only $10 \mathrm{~min}$. The effect after brief contact could not have been caused by a residue of stimulatory medium left after washing the cells. The residue after two washings was much less than $0 \cdot 25 \mathrm{ml}$., which was inactive (Table 1).

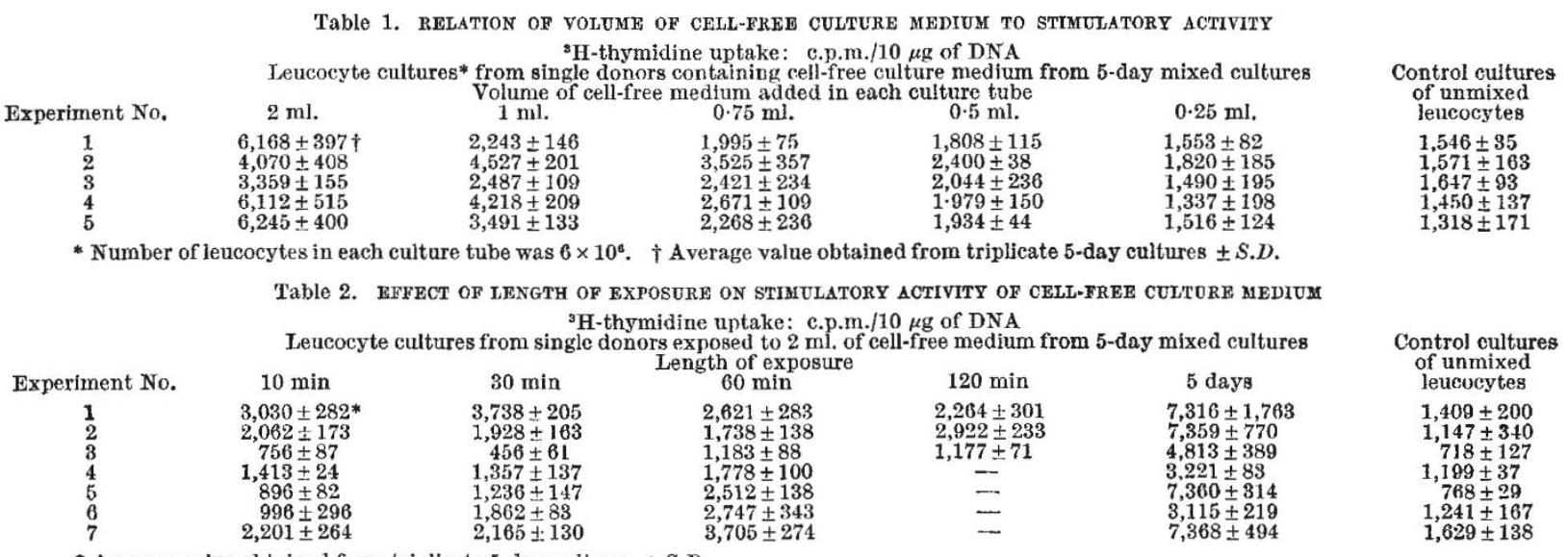

in leucocyte cultures, $2 \mathrm{ml}$. of cell-free medium was added to each tube containing freshly prepared cultures of leucocytes from single subjects. After incubation for $10,30,60$ or $120 \mathrm{~min}$, three culture tubes were centrifuged at 1,500 r.p.m. for $10 \mathrm{~min}$. The supernatants were decanted and the cells were resuspended in medium 199. The cells were washed twice with $4 \mathrm{ml}$. of medium 199 and were finally resuspended in medium 199 containing 20 per cent fresh pooled plasma. Control cultures, which had not been exposed to cell-free medium from 5-day mixed cultures, were also washed after incubation for $10 \mathrm{~min}$ and resuspended in fresh medium with plasma. At the same time, three culture tubes containing stimulatory cell-free culture medium were washed twice with medium 199 and the cells were resuspended in the original culture medium which had been removed after the first centrifugation and set aside. The cultures were incubated at $37^{\circ} \mathrm{C}$ for 5 days.

At the end of the incubation period, tritiated thymidine (specific activity $5 \cdot 0 \mathrm{Ci} /$ mmole) was added to each tube to give a concentration of $1 \mu \mathrm{Ci} / \mathrm{ml}$. After incubation for $2 \mathrm{~h}$ at $37^{\circ} \mathrm{C}$, the cells wero washed once in cold physiological
It seems pertinent that an irreversible process leading to blast cell transformation developed in leucocyte cultures from single subjects after contact for $60 \mathrm{~min}$, or sometimes only $10 \mathrm{~min}$, with cell-free medium derived from mixed leucocyte cultures.

We were supported by a grant from the Medical Research Council of Canada.

\section{ShINPEI KasaKURA} LOUIS LOWENBTEIN

Division of Haematology, Department of Medicine, Royal Victoria Hospital, and McGill University Clinic, Montreal, Canada.

Received March 15; revised May 21, 1968.

1 Kasakura, S., and Lowenstein, L., Nature, 208, 795 (1965). 'Kasakura, S., and Lowenstein, L., Ser. Haem., 11, 201 (1965).

3 Gordon, J., and MacLean, L. D., Nature, 208, 796 (1965).

'Bain, B., Vas, M. R., and Lowenstein, L., Blood, 28, 108 (1964).

'Schmidt, G., and Tannhauser, S. J., J. Biol. Chem., 161, 83 (1945).

'Kerr, V. N., Hayes, F. N., and Ott, D. G., Intern. J. App. Rad. Isotopes, 1, 